\title{
Isolation and Characterisation of L. plantarum O1 Producer of Plantaricin as Potential Starter Culture for the Biopreservation of Aquatic Food Products
}

\author{
Iva Čanak', Ksenija Markov', \\ Ena Melvan', Antonio \\ Starčević ${ }^{\prime}$, Mattea Živković1, \\ Manuela Zadravec², \\ Jelka Pleadin², Željko \\ Jakopović ${ }^{1}$, Deni Kostelac ${ }^{1}$ \\ and Jadranka Frece ${ }^{1 *}$
}

'Faculty of Food Technology and Biotechnology, University of Zagreb, Pierottijeva 6, HR-10000 Zagreb, Croatia

${ }^{2}$ Croatian Veterinary Institute, Savska 143, HR-10000 Zagreb, Croatia

Received: 6 February 2018 Accepted: 11 October 2018

\footnotetext{
${ }^{*}$ Corresponding author:

Phone: +38514605284;

Fax: +38514836424;

E-mail:jgoreta@pbf.hr

ORCID IDs: 0000-0003-0973-138X (Čanak), 0000-0001-9188-366X (Markov), 0000-0002-3437-2887 (Melvan), 0000-0003-2386-2124 (Starčević), 0000-0001-7923-435X (Živković), 0000-0003-4382-4424 (Zadravec), 0000-0002-0768-0462 (Pleadin), 0000-0001-6448-484X (Jakopović), 0000-0002-1120-2965 (Kostelac), 0000-0003-1022-4377 (Frece)
}

\section{SUMMARY}

Lactobacillus plantarum $\mathrm{O} 1$ was isolated from the gut of sea bream (Sparus aurata) and identified with the API biochemical test and MALDI-TOF MS. This strain was further characterised according to the selection criteria for lactic acid bacteria as starter cultures for aquatic food production. L. plantarum $\mathrm{O} 1$ showed good antimicrobial activity against pathogenic test microorganisms. Further investigation confirmed it as the producer of the bacteriocin plantaricin. This strain also showed good growth at a wide range of temperatures (from 4 to $45^{\circ} \mathrm{C}$ ) and a wide range of $\mathrm{pH}(2-12)$, even in the presence of $3.5 \% \mathrm{NaCl}$. Its viability was also good after lyophilisation and in simulated gastric and small intestinal juice. The strain is a promising probiotic, and our further research will focus on its application in the biopreservation of fresh fish and shellfish.

Key words: lactic acid bacteria, plantaricin, L. plantarum

\section{INTRODUCTION}

Fish and shellfish have useful microbes in their digestive systems and mucus that can be used to conserve fresh fish and live bivalve molluscs. Their use can prevent the development of pathogenic microflora, especially in shellfish consumed raw or undergoing only a slight thermal treatment. However, this effect of the cultured bacteria depends on the type of aquatic organisms from which the culture has been obtained, on the type of product to be preserved, and on the technology used to prepare the product for the market (1).

Lactic acid bacteria (LAB) are often used as starter cultures in the production and preservation of food products like dairy products, fermented vegetables, meat and silage, as they significantly improve flavour and produce antimicrobial compounds (2). These compounds include organic acids such as lactic acid, diacetyl, fatty acids, $\mathrm{CO}_{2}$, peroxide, and bacteriocins (3). Bacteriocins produced by LAB are of great interest for the food fermentation industry because they inhibit food spoilage and pathogenic bacteria, such as Staphylococcus aureus, Listeria monocytogenes, Bacillus cereus and Clostridium botulinum (4). Furthermore, as the most of bacteriocin-producing LAB are natural food isolates, they are ideal for application in food industry. They are common in the gastrointestinal tract of various endothermic animals (5), in milk and dairy products (6), seafood products (7), and on some plant surfaces (8). Yet, their presence in fish has been poorly studied (9).

Therefore, the aim of this study is to isolate LAB from sea bream as potential bacteriocin producers, and characterise them as starter cultures for aquatic products. Another reason that we opted for the marine strain is that terrestrial strains of probiotic bacteria have shown limited success with fish and shellfish, because strain characteristics depend on the environment in which they thrive. Looking for probiotic bacteria from the marine environment is a better approach (10). Chahad et al. (11) believe that using LAB in the same environment from which they were isolated ensures better adaptation and greater efficiency as natural antimicrobial agents. Furthermore, Leroi (12) suggests that LAB from terrestrial sources might change the organoleptic properties of marine food. 


\section{MATERIALS AND METHODS}

\section{L. plantarum $\mathrm{O} 1$ isolation and identification}

Lactobacillus plantarum $\mathrm{O} 1$ was isolated from the gut content of sea bream and identified with the analytical profile index (API) biochemical test-API 50 CHL (bioMérieux, Marcy-I'Étoile, France) with $99.9 \%$ similarity with the L. plantarum from the API database. Identification was confirmed with the score of 2.555 on a Microflex $\mathrm{LT}^{\mathrm{TM}}$ matrix-assisted laser desorption-ionisation time-of-flight mass spectrometer (MALDI-TOF MS; Bruker Daltonik, Bremen, Germany) using the procedure described by Frece et al. (13), as well as with the amplified fragment length polymorphism (AFLP) DNA fingerprinting analysis (BCCMTM/LMG Identification Service, Ghent, Belgium) (Fig. 1). Further confirmation was done on the liquid chromatography-electrospray ionization tandem mass spectrometer (LC-MS/MS ESI; SYNAPT G2-Si with nanoACQUITY UPLC system, Waters, Milford, MA, USA).

The culture was stored in a $50 \%$ glycerol solution (Gram-Mol, Zagreb, Croatia) at $-80^{\circ} \mathrm{C}$. Before analysis, the strain was recovered in MRS broth (Biolife, Milan, Italy) and incubated without shaking at $37{ }^{\circ} \mathrm{C}$. L. plantarum $\mathrm{O} 1$ has been deposited in the Deutsche Sammlung von Mikroorganismen und Zellkulturen GmbH (DSMZ), Braunschweig, Germany, as strain DSM 32196.

\section{Preparation of bacterial cell suspension}

After the overnight $L$. plantarum $\mathrm{O} 1$ culture was centrifuged (Z206A; Hermle Labortechnik GmbH, Wehningen, Germany) at $8000 \times g$ for $10 \mathrm{~min}$, the supernatant was removed and cells washed in $0.5 \%$ sterile saline (Gram-Mol), centrifuged again, and resupended in $5 \mathrm{~mL}$ of $0.5 \%$ saline.

\section{Determination of optimal growth conditions}

Cell growth was tested in MRS broth at different temperatures $\left(4,13,28,37,45\right.$ and $\left.60^{\circ} \mathrm{C}\right)$ and different $\mathrm{pH}$ values (2.0, $4.0,6.0,8.0,10.0$ and 12.0) for $24 \mathrm{~h}$. Experiment was conducted with initial number of $10^{7} \mathrm{CFU} / \mathrm{mL}$ in all the samples. Because tolerance to salt affects the viability of the starter cultures, we also tested the effect of $3.5 \% \mathrm{NaCl}$ (Gram-Mol). To determine optimal $\mathrm{pH}$, the bacterial cells were prepared as described in the section above, inoculated in MRS broth (Biolife), and incubated at $37^{\circ} \mathrm{C}$ for $24 \mathrm{~h}$. The MRS broth $\mathrm{pH}$ was adjusted and monitored with a pH meter (Mettler-Toledo, Greifensee, Switzerland). After the preparation of serial dilutions, the inoculated MRS agar (Biolife) plates were incubated at $37^{\circ} \mathrm{C}$ for $48 \mathrm{~h}$.

\section{Lactic acid and glucose concentration measurements}

Lactic acid and glucose concentrations were determined with a high-pressure liquid chromatograph (LC-10A $A_{v p}$ Shimadzu, Kyoto, Japan) as described by Babić et al. (14). Glucose, lactic acid, acetate and ethanol were purchased from Sigma-Aldrich, Merck (St. Louis, MO, USA). $\mathrm{H}_{3} \mathrm{PO}_{4}$ ( $85 \%$ by volume; Sigma-Aldrich, Merck) was used to prepare the mobile phase $\left(0.1 \%\right.$ by volume $\left.\mathrm{H}_{3} \mathrm{PO}_{4}\right)$, and deionised water with conductivity $<1 \mu S$ was used to prepare the mobile phase and standard solutions. Piston pump ( $\left.L C-10 A D_{V p}\right)$ delivered the mobile phase at $0.5 \mathrm{~mL} / \mathrm{min}$. Substrate and product were separated using a Supelcogel ${ }^{\mathrm{TM}} \mathrm{C}-610 \mathrm{H}(30 \mathrm{~cm} \times 7.8 \mathrm{~mm}$, i.d. $9 \mu \mathrm{m})$ analytical column with a Supelcogel ${ }^{\mathrm{TM}} \mathrm{H}(5 \mathrm{~cm} \times 4.6 \mathrm{~mm}$, i.d. $9 \mu \mathrm{m})$ guard column (both supplied by Sigma-Aldrich, Merck), and detected by a refractive index detector (RID-10A; Sigma-Aldrich, Merck). Instructions by Zúñiga et al. (15) were followed to determine whether L. plantarum $\mathrm{O} 1$ was homofermentative or heterofermentative. Briefly, cells of $L$. plantarum 01 overnight culture were centrifuged (Z206A; Hermle) at $8000 \times g$ for $10 \mathrm{~min}$, washed twice with distilled water and resuspended in $0.5 \mathrm{~mL}$ of the same solvent. A volume of $0.2 \mathrm{~mL}$ of thus prepared suspension was inoculated in HHD broth (Biolife). After incubation at $30^{\circ} \mathrm{C}$ for 3 days, strain was identified depending on medium colour (green for homofermentative; blue for heterofermentative).

\section{Antibiotic resistance of L. plantarum 01}

The antibiotic resistance of $L$. plantarum $\mathrm{O} 1$ was tested on MRS agar (Biolife) using the agar disc diffusion method as described by Frece et al. (13). The following antibiotic discs (BD-Becton, Dickinson and Company, Franklin Lakes, NJ, USA) were used: clindamycin $(2 \mu \mathrm{g})$; neomycin, methicillin and
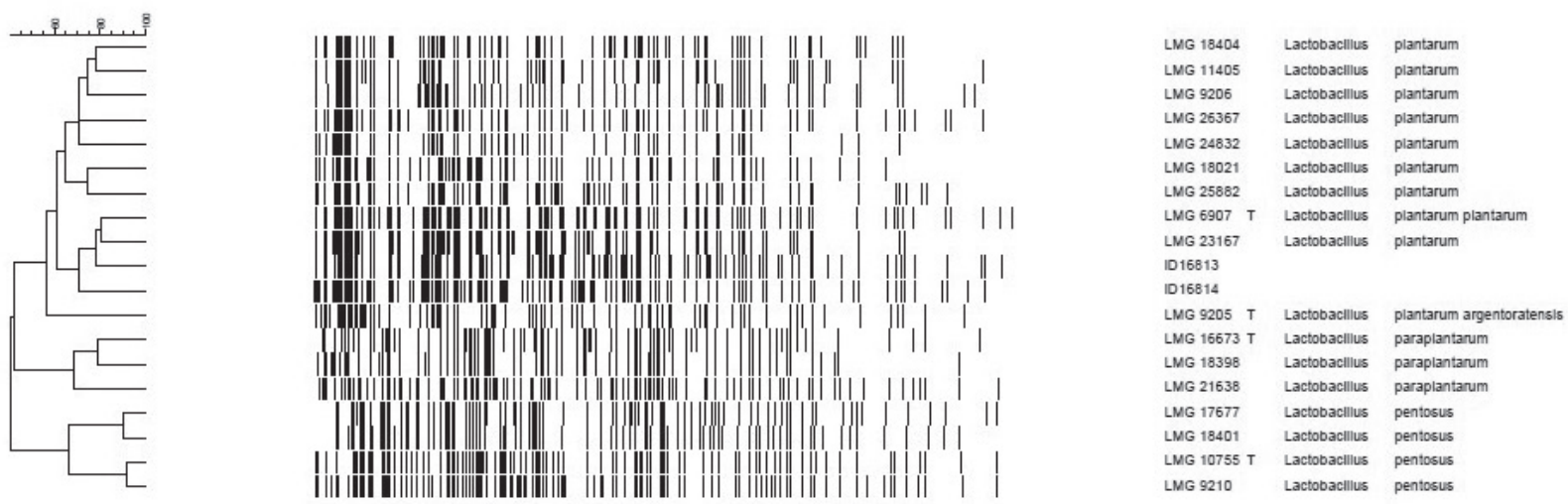

Fig. 1. Dendrogram obtained after AFLP identification of Lactobacillus plantarum O1, DSM 32196 (BCCMTM/LMG Identification Service, Ghent, Belgium) 
erythromycin (5 $\mu \mathrm{g}$ each); tobramycin, lincomycin and ampicillin (10 $\mu \mathrm{g}$ each); chloramphenicol, gentamycin, vancomycin, rifampicin and tetracycline (30 $\mu \mathrm{g}$ each). Appearance of transparent zone around grown colonies was a sign of antibiotic sensitivity.

\section{Determination of histamine production}

The culture was tested for histidine decarboxylase production according to Joosten and Northolt (16). Medium used for detection of decarboxylating bacteria contained (in \%): 0.5 tryptone (Biolife), 0.5 yeast extract (Biolife), $0.5 \mathrm{NaCl}$ (Gram-Mol) 0.1 glucose (Gram-Mol), 0.05 Tween 80 (Biolife), $0.02 \mathrm{MgSO}_{4} \cdot 7 \mathrm{H}_{2} \mathrm{O}$ (Kemika, Zagreb, Croatia), $0.01 \mathrm{CaCO}_{3}(\mathrm{Ke}-$ mika), 0.006 bromocresol purple (Kemika), $0.005 \mathrm{MnSO}_{4} \cdot 4 \mathrm{H}_{2} \mathrm{O}$ (Kemika), $0.004 \mathrm{FeSO}_{4} \cdot 7 \mathrm{H}_{2} \mathrm{O}$ (Kemika), 2 agar (Biolife), and 2 histidine (Sigma-Aldrich, Merck). After sterilisation (at $121^{\circ} \mathrm{C}$ for $10 \mathrm{~min}$ ), the $\mathrm{pH}$ was $5.0 \pm 0.1$. Cells of $L$. plantarum $\mathrm{O} 1$ overnight culture were centrifuged (Z206A; Hermle) at $8000 \times g$ for $10 \mathrm{~min}$, washed twice with distilled water and resuspended in $0.5 \mathrm{~mL}$ of the same solvent. A volume of $0.1 \mathrm{~mL}$ of thus prepared suspension was inoculated in the middle of the plate (without spreading) and plates were incubated anaerobically at $37^{\circ} \mathrm{C}$ for five days. Test was positive for amine production if the fully grown colonies were surrounded by a purple halo.

\section{Determination of antimicrobial activity}

We tested the antimicrobial activity of L. plantarum $\mathrm{O} 1$ against Escherichia coli ATCC 25922, Staphylococcus aureus ATCC 25923, Proteus mirabilis ATCC 25933, Pseudomonas aeruginosa ATCC 27853, Listeria monocytogenes ATCC 23074 and Vibrio sp. 3013 using the turbidimetric methods described by Babić et al. (14). Briefly, $240 \mu \mathrm{L}$ of LAB supernatant were added into the wells of microtiter plate together with 10 $\mu \mathrm{L}$ of test microorganism. Antibacterial activity of LAB culture towards pathogenic microorganisms was monitored during eight hours at $37^{\circ} \mathrm{C}$, spectrophotometrically, by measuring the absorbance at $620 \mathrm{~nm}$ every 2 hours using a microtiter plate reader (Sunrise, Tecan, Männedorf, Switzerland). Positive control was the growth of each pathogen in nutrition broth, while the growth of L. plantarum $\mathrm{O} 1$ in MRS broth presented negative control. The pathogens were obtained from the collection of microorganisms of the Laboratory for General Microbiology and Food Microbiology, Department of Biochemical Engineering, Faculty of Food Technology and Biotechnology, University of Zagreb, Croatia. To exclude inhibitory effect of lactic acid, cell-free supernatant of L. plantarum $\mathrm{O} 1$ was adjusted to $\mathrm{pH}=6.5$ with sterile $1 \mathrm{M} \mathrm{NaOH}$ (Gram-Mol).

\section{Bacteriocin assay}

Bacteriocin antimicrobial activity was tested using well diffusion assay. Briefly, $1 \mathrm{~mL}$ of test microorganism (E. coli, S. aureus, P. mirabilis, P. aeruginosa, L. monocytogenes, Vibrio sp.) was inoculated on tryptic soy agar (Biolife) and air dried for 5 $\mathrm{min}$. Wells of $5 \mathrm{~mm}$ were made in each agar plate and filled with $100 \mu \mathrm{L}$ of cell-free supernatant of L. plantarum 01, previously neutralised with sterile $1 \mathrm{M} \mathrm{NaOH}$ (Gram-Mol) to exclude the inhibitory effect of lactic acid. Same volume of sterilised MRS broth (Biolife) added to wells served as control. We looked for the inhibition zones as a sign of antagonistic activity.

We then tested L. plantarum $\mathrm{O} 1$ for the presence of bacteriocins using an LC-MS/MS ESI (Synapt G2-Si; Waters). Sample preparation followed a fairly standard protocol (Thermo Fisher Scientific), which includes protein isolation and protein digestion using trypsin. Peptides were separated using ultra-performance liquid chromatography (nanoACQUITY UPLC system (Waters) equipped with a sample manager and two binary solvent managers) and the samples finally analysed with an electrospray LC-MS/MS using data-dependent acquisition in positive mode. For peptide fragmentation we used a trap collision cell with argon as the collision gas in ESI+ mode.

\section{DNA isolation}

Total genomic DNA was isolated from L. plantarum $\mathrm{O} 1$ with a NucleoSpin ${ }^{\circledast}$, Microbial DNA kit (Macherey-Nagel, Düren, Germany) following manufacturer's instructions. Briefly, microbial DNA was obtained by combination of NucleoSpin ${ }^{\circledast}$ Bead Tubes Type B, liquid Proteinase K (Macherey-Nagel), and disruption device. DNA binding conditions to the NucleoSpin ${ }^{\circledast}$ Microbial DNA columns were achieved by addition of large amounts of chaotropic salts (binding buffer MG) to the lysate. Contaminants were removed by two washing steps. DNA was eluted with a slightly alkaline buffer (BE buffer).

\section{Detection of plantaricin-related genes with $P C R$}

In order to investigate the presence of some genes included in the $p / n$ locus, plantaricin-related genes $p / n A, p / n E F, p / n$ NC8 and $p / n W$ were identified using the PCR primers shown in Table 1. The procedure was as follows: denaturation at $95^{\circ} \mathrm{C}$ for 5 min followed by 30 cycles of denaturation at $94^{\circ} \mathrm{C}$ for $30 \mathrm{~s}$, annealing at specific temperature for each primer for 1 min, and polymerisation at $72^{\circ} \mathrm{C}$ for $1 \mathrm{~min}$. The obtained amplification fragment patterns were analysed with gel electrophoresis at $100 \mathrm{~V}$ in $1 \%$ agarose gel (Sigma-Aldrich, Merck).

Table 1. Primers used for the PCR

\begin{tabular}{|c|c|c|}
\hline Primer & Sequence & $\begin{array}{c}\begin{array}{c}\text { Annealing } \\
\text { temperature }\end{array} \\
\frac{{ }^{\circ} \mathrm{C}}{}\end{array}$ \\
\hline PInA-for & 5'-ATGAAAATTCAAATTAAAGGTATGAAGC-3' & \multirow{2}{*}{53} \\
\hline PInA-rev & 5'-TTACCATCCCCATTTTTTAAACAGTTTC-3' & \\
\hline PInEF-for & 5'-GGCATAGTTAAAATTCCCCCC-3' & \multirow{2}{*}{53.2} \\
\hline PInEF-rev & 5'-CAGGTTGCCGCAAAAAAA G-3' & \\
\hline PlnNC8-for & 5'-GGTCTGCGTATAAGCATCGC-3' & \multirow{2}{*}{60} \\
\hline PInNC8-rev & 5'-AAATTGAACATATGGGTGCTTTAAATTCC-3' & \\
\hline PInW-for & 5'-TCACACGAAATATTCCA-3' & \multirow{2}{*}{55} \\
\hline PInW-rev & 5'-GGCAAGCGTAAGAAATAAATGAG-3' & \\
\hline
\end{tabular}


Isolate survival in gastric and small intestinal juice simulations

In order to act as a probiotic in the gastrointestinal tract and exert beneficial effect on the host, bacteria must be able to survive actions of acid in stomach, and bile acids at the beginning of the small intestine (17).

Gastric and small intestinal juice simulations were prepared according to Frece et al. (13). Gastric juice was prepared by suspending $3 \mathrm{~g} / \mathrm{L}$ of pepsin (Sigma-Aldrich, Merck) in sterile $\mathrm{NaCl}(\mathrm{Gram}-\mathrm{Mol})$ solution $(0.5 \%)$ and adjusting the $\mathrm{pH}$ to 2.0 with concentrated $\mathrm{HCl}$ (Gram-Mol). Small intestinal juice was prepared by suspending pancreatin $(1 \mathrm{~g} / \mathrm{L})$ and bile salts ( $2 \mathrm{mg} / \mathrm{mL}$ of oxgall, i.e. dehydrated fresh bile) in a sterile $\mathrm{NaCl}$ solution $(0.5 \%)$ and adjusting the $\mathrm{pH}$ to 8.0 with $0.1 \mathrm{~mol} / \mathrm{L}$ of $\mathrm{NaOH}$ (Gram-Mol). Pancreatin (from hog pancreas, $165 \mathrm{U} / \mathrm{mg}$ ) and oxgall were obtained from Sigma-Aldrich, Merck.

Washed cell suspensions of $L$. plantarum $01(0.6 \mathrm{~mL}$, approx. $10^{7} \mathrm{CFU} / \mathrm{mL}$ ) were vortexed (V-1 Plus; Biosan, Riga, Latvia) separately with gastric or small intestinal juice $(3 \mathrm{~mL})$ and $0.9 \mathrm{~mL}$ of $0.5 \% \mathrm{NaCl}$. Changes in total viable count were monitored for $2 \mathrm{~h}$ in gastric and $4 \mathrm{~h}$ in small intestinal juice using the pour plate method (18). From samples containing bacterial cells, decimal dilutions were prepared in sterile water and spread on MRS agar plates (Biolife). The plates with MRS were incubated at $37^{\circ} \mathrm{C}$ for $24 \mathrm{~h}$. The log $\mathrm{CFU} / \mathrm{mL}$ is expressed as the percentage of $L A B$ viability.

\section{Survival during lyophilisation and storage}

Cells of L. plantarum 01 cultivated overnight in MRS broth were collected by centrifugation (Z206A; Hermle) (8000×g for $15 \mathrm{~min})$, washed, and $100 \mathrm{mg}$ of fresh biomass was resuspended in $1 \mathrm{~mL}$ of skimmed milk. After overnight freezing at $-20^{\circ} \mathrm{C}$, the cells were lyophilised in a BenchTop freeze-dryer (Alpha 1-2 LD Plus; Christ, Osterode am Harz, Germany). Cell survival was determined on MRS agar (Biolife) using the standard pour plating method (18).

\section{RESULTS AND DISCUSSION}

In order to investigate new strains of marine origin with potential application in biopreservation, we isolated lactobacilli from the gut of sea bream. Dominant strain was Lactobacillus plantarum $\mathrm{O} 1$. We identified it with API biochemical test and MALDI-TOF. Further confirmation was done with AFLP DNA fingerprinting and LC-MS/MS ESI which involved matching the resulting 51415 MS2 spectra against the GenBank 'nr' protein dataset digested in silico with trypsin. The 407 best scoring MS2 spectra were used to identify the strain. The results confirmed $L$. plantarum, with the closest match being $L$. plantarum ssp. plantarum P-8 (Table 2).

Temperature and $\mathrm{pH}$ affect the viability, growth, and the competitiveness of starter cultures during fermentation and ripening (19). Of all the tested temperatures $(4,13,28,37,45$ and

Table 2. LC-MS/MS strain identification based on 407 top scoring MS2 spectra allotted to the NCBI taxa containing trypsin-digested peptide fragment matches

\begin{tabular}{|c|c|c|c|}
\hline Species & $\begin{array}{c}\text { Top scoring MS2 } \\
\text { fragment }\end{array}$ & $\begin{array}{l}\text { Database search } \\
\text { space }\end{array}$ & $\begin{array}{c}\text { Identification } \\
\text { probability }\end{array}$ \\
\hline Lactobacillus plantarum & 233 & 5390 & 100.00 \\
\hline Lactobacillus plantarum ssp. plantarum P-8 & 180 & 2557 & 77.16 \\
\hline Lactobacillus plantarum WCFS1 & 179 & 2640 & 76.72 \\
\hline Lactobacillus plantarum ZJ316 & 179 & 2558 & 76.72 \\
\hline Lactobacillus plantarum UCMA 3037 & 175 & 2425 & 75.00 \\
\hline Lactobacillus plantarum ssp. plantarum ATCC 1491 & 175 & 2604 & 75.00 \\
\hline Lactobacillus plantarum ssp. plantarum NC8 & 170 & 2470 & 72.84 \\
\hline Lactobacillus plantarum IPLA88 & 169 & 2480 & 72.41 \\
\hline Lactobacillus plantarum ssp. plantarum ST-III & 168 & 2536 & 71.98 \\
\hline Lactobacillus plantarum JDM1 & 166 & 2364 & 71.12 \\
\hline Lactobacillus pentosus & 139 & 2190 & 59.48 \\
\hline Lactobacillus pentosus KCA1 & 138 & 2146 & 59.05 \\
\hline Lactobacillus pentosus IG1 & 134 & 2137 & 57.33 \\
\hline Lactobacillus pentosus MP-10 & 132 & 2096 & 56.47 \\
\hline Lactobacillus brevis & 127 & 3414 & 54.31 \\
\hline Lactobacillus brevis ssp. gravesensis ATCC 27305 & 70 & 1061 & 29.74 \\
\hline Lactobacillus brevis KB290 & 60 & 716 & 25.43 \\
\hline Lactobacillus brevis ATCC 367 & 50 & 515 & 21.12 \\
\hline Lactobacillus buchneri & 48 & 1278 & 20.26 \\
\hline Lactobacillus buchneri ATCC 11577 & 48 & 723 & 20.26 \\
\hline Lactobacillus hilgardii ATCC 8290 & 45 & 683 & 18.97 \\
\hline Lactobacillus hilgardii & 34 & 327 & 14.22 \\
\hline Lactobacillus parafarraginis & 17 & 333 & 6.90 \\
\hline
\end{tabular}


$\left.60^{\circ} \mathrm{C}\right)$, the culture grew best at $37^{\circ} \mathrm{C}\left(5 \cdot 10^{\circ} \mathrm{CFU} / \mathrm{mL}\right)$ and showed moderate growth at $28^{\circ} \mathrm{C}\left(2 \cdot 10^{\circ} \mathrm{CFU} / \mathrm{mL}\right)$. At 13 and $4{ }^{\circ} \mathrm{C}$, number of cells was maintained and was similar to the inoculation level of 3.2.1 $10^{7}$ and $2.5 \cdot 10^{7} \mathrm{CFU} / \mathrm{mL}$, respectively. At $45^{\circ} \mathrm{C}$, cell survival was $6 \cdot 10^{4} \mathrm{CFU} / \mathrm{mL}$, and at $60^{\circ} \mathrm{C}$ no growth was detected. Our findings corroborate those of Ahmed et al. (20), who reported optimal growth temperature for $L A B$ between 30 and $40^{\circ} \mathrm{C}$. A particular advantage of our isolate is that it can grow at $4^{\circ} \mathrm{C}$, i.e. at low temperatures used for cold storage of fresh aquatic products. This result is in accordance with Ghanbari et al. (21), who claim that seafood-borne $L A B$ can often stand refrigeration temperatures as well as the environment in which seafood is preserved, such as low $\mathrm{pH}$ and high salt concentrations.

Our isolate showed the highest survival at $\mathrm{pH}=4$, but retained good survival at a wide $\mathrm{pH}$ range from 2 to 12 . This feature is important for starter cultures, as they are usually exposed to unfavourable $\mathrm{pH}$ during industrial processing (13).

Similarly, L. plantarum $\mathrm{O} 1$ showed relatively good survival in the presence of $3.5 \% \mathrm{NaCl}\left(10^{6} \mathrm{CFU} / \mathrm{mL}\right)$ and could therefore be used for marinating sea products. Its survival at such high salt concentration is probably owed to the cell membrane stability and the ability to resist osmotic stress $(22,23)$.
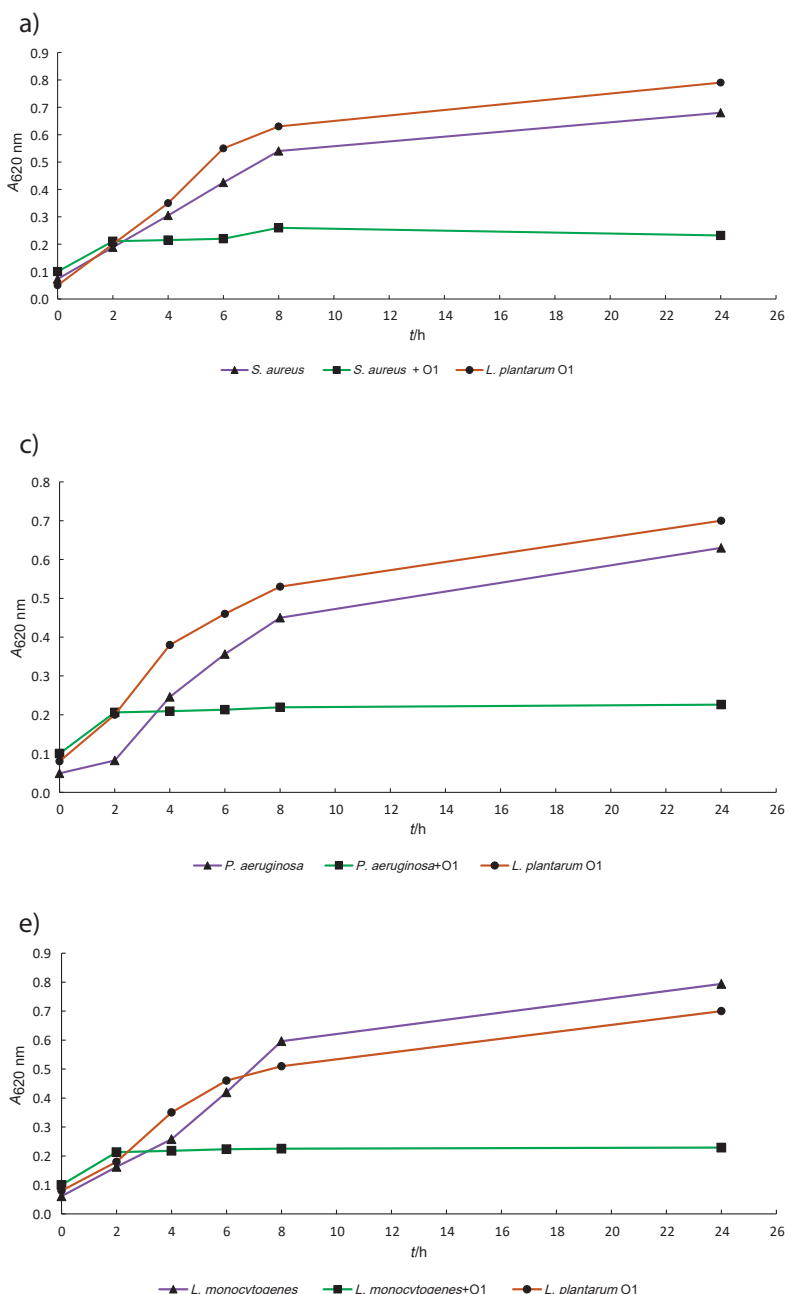

One of the most important properties of functional starter cultures is the growth inhibition of pathogens. Initial absorbance of all experimental groups was in the range of $0.05-0.2 \mathrm{~nm}$. After $24 \mathrm{~h}$, the survival of test pathogens in the presence of $L A B$ strain was in range $0.19-0.54 \mathrm{~nm}$. Our isolate showed good growth inhibition in all test microorganisms. Their 24-hour survival ranged from $15 \%$ in E. coli, $19 \%$ in $L$. monocytogenes, $18 \%$ in P. aeruginosa, $17 \%$ in Vibrio sp. and $20 \%$ in P. mirabilis to $21 \%$ in S. aureus (Figs. 2a-2f). Similar inhibitions were reported by Klingberg et al. (24) for E. coli, S. Typhimurium, and L. monocytogenes.

The well diffusion assay for bacteriocin antimicrobial activity confirmed the inhibition findings. It showed the highest inhibition zone for E. coli $(40 \mathrm{~mm})$, moderate for L. monocytogenes (38 mm), P. aeruginosa (37 mm), Vibrio sp. (38 mm), and the lowest for S. aureus $(25 \mathrm{~mm})$ and $P$. mirabilis $(22 \mathrm{~mm})$. Furthermore, our LC-MS/MS ESI confirmed the presence of several peptides specific for bacteriocin production by $L$. plantarum $\mathrm{O} 1$ (Table 3, Fig. 3).

The presence of other bacteriocin-related proteins, such as bacteriocin immunity protein, reinforces our findings, as this protein protects against self-toxicity. Ultimately, the

b)

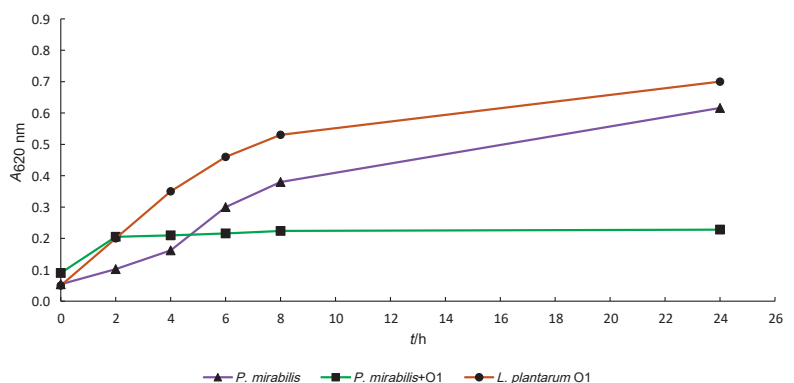

d)

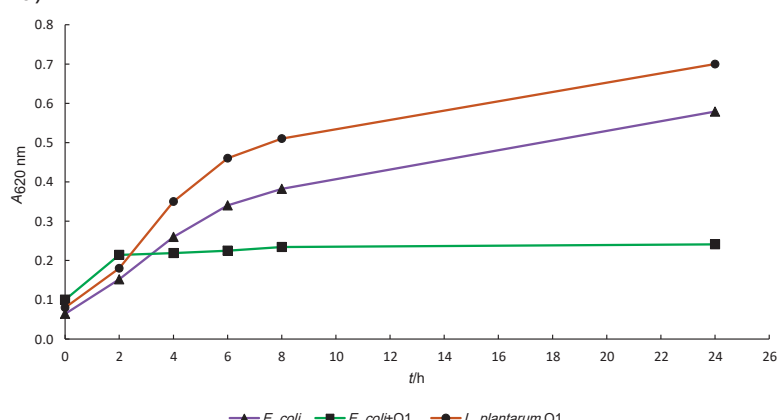

f)

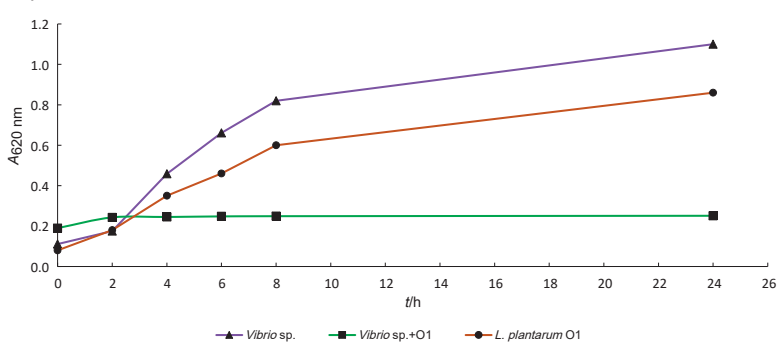

Fig. 2. Growth of pathogenic microorganisms in the presence of Lactobacillus plantarum O1: a) P. mirabilis, b) S. aureus, c) P. aeruginosa, d) E. coli, e) L. monocytogenes, f) Vibrio sp. Brown line: negative control, purple line: positive control, green line: pathogen with L. plantarum 01 
Table 3. Bacteriocin-related proteins identified by nano-liquid chromatography-tandem mass spectrometry (Waters SYNAPT G2-Si with nanoACQUITY UPLC system) matched against GenBank 'nr' database

\begin{tabular}{lc} 
Identified protein & MS2 peptide fragment \\
PHY43767.1 bacteriocin immunity protein [Lactobacillus plantarum] & AIPELQQALAK \\
EMP43595.1 putative bacteriocin activator [Lactobacillus plantarum] & EYAGLSDTSGTLDSQFMAALLNMSAFTLVADGYEKIR \\
\hline
\end{tabular}

bacteriocin immunity protein [Lactobacillus plantarum] gi|1272548769|gb|PHY43767.1|

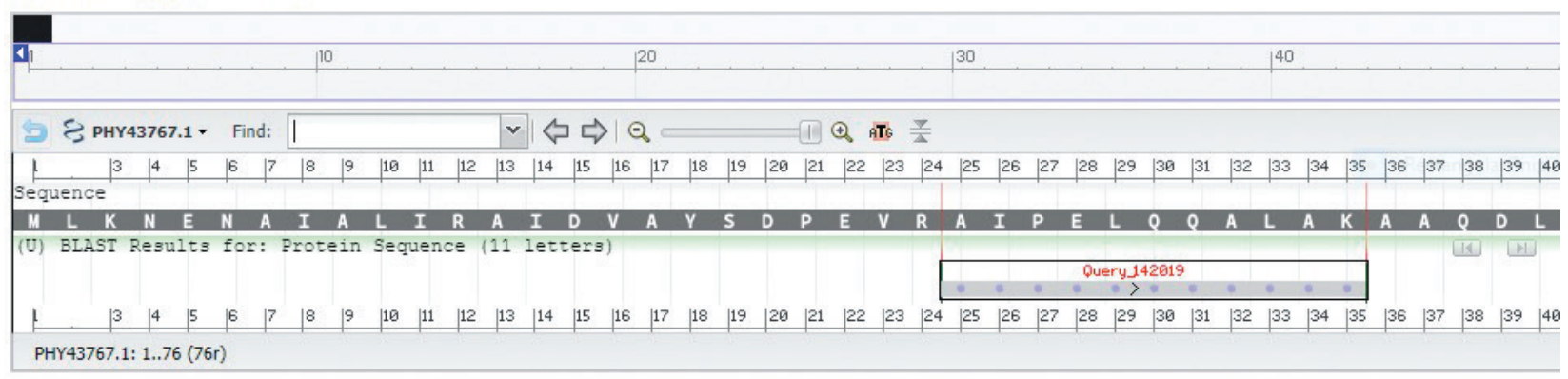

\section{Putative Bacteriocin activator [Lactobacillus plantarum UCMA 3037]}

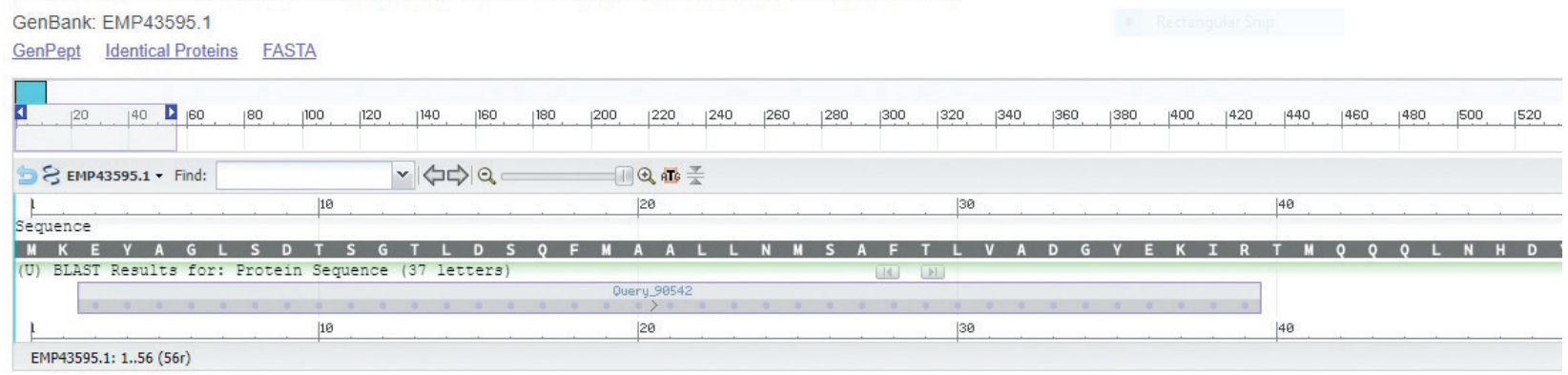

Fig. 3. Hits from the base after matching MS2 spectra against the GenBank 'nr' protein dataset

bacteriocin plantaricin was confirmed at the gene level with PCR. The encoding genes in L. plantarum 01 were positive for the $p$ InA gene (Fig. 4). Negative results were obtained for $p l-$ $n E F$, plnNC8 and plnW (data not shown).

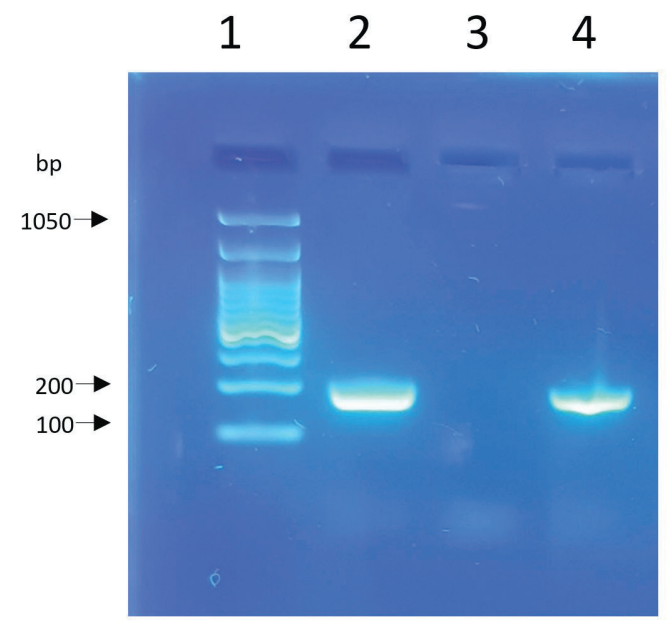

Fig. 4. PCR analysis of the $p \ln A$ gene in L. plantarum O1. Lane $1=$ markers (BenchTop 100 bp DNA Ladder, Promega, Madison, WI, USA), lane $2=$ Lactobacillus plantarum C11 (positive control), lane 3=Lactococcus lactis ssp. cremoris MG 1363 (negative control) 4=Lactobacillus plantarum $\mathrm{O} 1$
PInA is peptide pheromone, inducer of bacteriocin production (25), but it also acts against specific microbial strains (26). PInA reacts with the membrane lipids before binding to the receptor that induces pheromone activity (27). The antimicrobial activity against sensitive pathogen microorganisms is probably due to initial interaction with the cell membrane.

The production of lactic acid, and decrease in the $\mathrm{pH}$, prevents the growth of spoilage microorganisms and improves the quality and safety of the final product (14). Our strain was homofermentative, did not produce gas from glucose, and produced high levels of lactic acid ((21.96 11.1) g/L). These findings are in agreement with Bonomo et al. (28), who stated that $65 \%$ of LAB strains had good producing capacity of lactic acid.

Seafood products have already been associated with high amounts of biogenic amines $(29,30)$, but little has been reported about histamine production by LAB strains. Judging by the complete absence of purple colonies with purple halos, our strain does not produce histamine. Similar was reported by Bover Cid et al. (31) and Moreno-Arribas et al. (32) for some $\mathrm{LAB}$ isolates.

Before considering a $L A B$ strain for the biopreservation of food products, some safety aspects, including antibiotic resistance and sensitivity, need to be established (33). Research over the past years has shown that starter cultures can 
become resistant to some antibiotics of therapeutic importance $(34,35)$. Our strain was sensitive to all antibiotics tested and is not expected to interfere with clinical treatment.

It also showed good survival after exposure to pepsin in stomach (75.33\%) and pancreatin and bile salts in the small intestine juice simulations (89.68\%). In an earlier study, Ramesh et al. (36) suggested that probiotic bacteria should have higher tolerance to bile. Bile tolerance may be related to the isolate's ability to hydrolyse bile salt with bile salt hydrolase, as suggested by De Smet et al. (37). Similar observations were also made by Mukherjee and Ghosh (38) and Dutta et al. (39), who investigated bile tolerance of some promising probiotic bacteria for aquaculture application.

In industrial application, bacteria are exposed to stress associated with mechanical processing, heat treatment and chemical microenvironment (40). Processes such as freeze-drying and vacuum-drying do osmotic damage to probiotic cells and disrupt the cell membrane (18). We treated $L$. plantarum $\mathrm{O} 1$ with skimmed milk as lyoprotectant, and, judging by its high survival rate $(98.21 \%)$, it resisted well the stress connected to lyophilisation.

\section{CONCLUSIONS}

The Lactobacillus plantarum $\mathrm{O} 1$ we isolated and characterised in this paper is one of the $L A B$ species with a high degree of tolerance to elevated osmolarity and survival at refrigeration temperature. It is highly efficient against the common spoilage and pathogenic strains in aquatic food products and does not produce histidine decarboxylase. All these characteristics indicate that L. plantarum $\mathrm{O} 1$ has a promising potential, and our further research will focus on its application in the biopreservation of fresh fish and shellfish.

\section{ACKNOWLEDGEMENTS}

We are grateful to the Croatian Agency for SMEs (Small and Medium-sized Enterprises), Innovations and Investments (HAMAG-BICRO) for financing the project 'Application of biopreservation methods on aquaculture products: An ecological approach to food safety improvement and shelf life extension', under the program Proof of Concept (PoC). The authors also wish to thank Mr Dado Čakalo for help in editing this article.

\section{CONFLICT OF INTEREST}

None to declare.

\section{REFERENCES}

1. de Bidhan C, Meena DK, Behera BK, Das P, Das Mohapatra PK, Sharma AP. Probiotics in fish and shellfish culture: Immunomodulatory and ecophysiological responses. Fish Physiol Biochem. 2014;40(3):921-71.

https://doi.org/10.1007/s10695-013-9897-0
2. de Vries MC, Vaughan EE, Kleerebezem M, de Vos WM. Lactobacillus plantarum - Survival, functional and potential probiotic properties in the human intestinal tract. Int Dairy J. 2006;16(9):1018-28.

https://doi.org/10.1016/j.idairyj.2005.09.003

3. Kleerebezem M, Kuipers OP, Smid EJ. Editorial: Lactic acid bacteria - A continuing journey in science and application. FEMS Microbiol Rev. 2017;41(Supp_1):S1-2. https://doi.org/10.1093/femsre/fux036

4. Stiles ME. Biopreservation by lactic acid bacteria. Antonie van Leeuwenhoek. 1996;70(2-4):331-45.

https://doi.org/10.1007/BF00395940

5. Tannock GW, Szylit O, Duval Y, Raibuad P. Colonization of tissue surfaces in the gastrointestinal tract of gnotobiotic animals by Lactobacillus strains. Can J Microbiol. 1982; 28(10):1196-8.

https://doi.org/10.1139/m82-177

6. Fguiri I, Ziadi M, Atigui M, Ayeb N, Arroum S, Assadi M, Khorchani T. Isolation and characterisation of lactic acid bacteria strains from raw camel milk for potential use in the production of fermented Tunisian dairy products. Int J Dairy Technol. 2016;69(1):103-13.

https://doi.org/10.1111/1471-0307.12226

7. Mauguin S, Novel G. Characterization of lactic acid bacteria isolated from seafood. J Appl Microbiol. 1994;76(6):616-25. https://doi.org/10.1111/j.1365-2672.1994.tb01660.x

8. Minervini F, Celano G, Lattanzi A, Tedone L, De Mastro G, Gobbetti M, De Angelis M. Lactic acid bacteria in durum wheat flour are endophytic components of the plant during its entire life cycle. Appl Environ Microbiol. 2015;81(19): 6736-48.

https://doi.org/10.1128/AEM.01852-15

9. Gómez-Sala B, Herranz C, Díaz-Freitas B, Hernández PE, Sala A, Cintas LM. Strategies to increase the hygienic and economic value of fresh fish: Biopreservation using lactic acid bacteria of marine origin. Int J Food Microbiol. 2016; 223(16):41-9.

https://doi.org/10.1016/j.ijfoodmicro.2016.02.005

10. Kang $\mathrm{CH}, \mathrm{Gu}$ T, So JS. Possible probiotic lactic acid bacteria Isolated from oysters (Crassostrea gigas). Probiotics Antimicro Prot. 2018;10(4):728-39. https://doi.org/10.1007/s12602-017-9315-5

11. Chahad OB, El Bour M, Calo-Mata P, Boudabous A, Barros-Velàzquez J. Discovery of novel biopreservation agents with inhibitory effects on growth of food-borne pathogens and their application to seafood products. Res Microbiol. 2012;163(1):44-54.

https://doi.org/10.1016/j.resmic.2011.08.005

12. Leroi F. Occurrence and role of lactic acid bacteria in seafood products. Food Microbiol. 2010;27(6):698-709. https://doi.org/10.1016/j.fm.2010.05.016

13. Frece J, Cvrtila J, Topić I, Delaš F, Markov K. Lactococcus lactis ssp. lactis as potential functional starter culture. Food 
Technol Biotechnol. 2014;52(4):489-94.

https://doi.org/10.17113/ftb.52.04.14.3794

14. Babić I, Markov K, Kovačević D, Trontel A, Slavica A, Đugum $J$, et al. Identifcation and characterization of potential autochthonous starter cultures from a Croatian "brand" product "Slavonski kulen". Meat Sci. 2011;88(3):517-24. https://doi.org/10.1016/j.meatsci.2011.02.003

15. Zúñiga $M$, Pardo I, Ferrer S. An improved medium for distinguishing between homofermentative and heterofermentative lactic acid bacteria. Int J Food Microbiol. 1993;18(1):37-42. https://doi.org/10.1016/0168-1605(93)90005-2

16. Joosten HMLJ, Northolt MD. Detection, growth, and amine-producing capacity of lactobacilli in cheese. Appl Environ Microbiol. 1989;55(9):2356-9.

17. Holzapfel WH, Haberer P, Snel J, Schillinger V, Huis in't Veld JHJ. Overview of gut flora and probiotics. Int J Food Microbiol. 1998;41(2):85-101. https://doi.org/10.1016/S0168-1605(98)00044-0

18. Kos B, Šušković J, Beganović J, Gjuračić K, Frece J, lannaccone $C$, Canganella F. Characterization of the three selected probiotic strains for the application in food industry. World J Microbiol Biotechnol. 2008;24(5):699-707. https://doi.org/10.1007/s11274-007-9528-y

19. Ammor MS, Mayo B. Selection criteria for lactic acid bacteria to be used as functional starter cultures in dry sausage production: An update. Meat Sci. 2007;76(1):138-46. https://doi.org/10.1016/j.meatsci.2006.10.022

20. Ahmed Z, Wang Y, Ahmad A, Khan ST, Nisa M, Ahmad H, Afreen A. Kefir and health: A contemporary perspective. Crit Rev Food Sci Nutr. 2013;53(5):422-34. https://doi.org/10.1080/10408398.2010.540360

21. Ghanbari M, Jami M, Domig KJ, Kneifel W. Seafood biopreservation by lactic acid bacteria - A review. LWT - Food Sci Technol. 2013;54(2):315-24.

https://doi.org/10.1016/j.lwt.2013.05.039

22. Linders LJM, Wolkers WF, Hoekstra FA, van't Riet K. Effect of added carbohydrates on membrane phase behavior and survival of dried Lactobacillus plantarum. Cryobiology. 1997;35(1):31-40.

https://doi.org/10.1006/cryo.1997.2021

23. Laroche C, Gervais P. Unexpected thermal destruction of dried, glass bead immobilized microorganisms as a function of water activity. Appl Environ Microbiol. 2003;69(5):3015-9. https://doi.org/10.1128/AEM.69.5.3015-3019.2003

24. Klingberg TD, Pedersen MH, Cencic A, Budde BB. Application of measurements of transepithelial electrical resistance of intestinal epithelial cell monolayers to evaluate probiotic activity. Appl Environ Microbiol. 2005;71(11):7528-30. https://doi.org/10.1128/AEM.71.11.7528-7530.2005

25. Hauge HH, Mantzilas D, Moll GN, Konings WN, Driessen AJ, Eijsink VGH, Nissen-Meyer J. Plantaricin A is an amphiphilic a-helical bacteriocin-like pheromone which exerts antimicrobial and pheromone activities through different mechanisms. Biochemistry. 1998;37(46):16026-32.

https://doi.org/10.1021/bi981532j

26. Zhao H, Sood R, Jutila A, Bose S, Fimland G, Nissen-Meyer $J$, Kinnunen PKJ. Interaction of the antimicrobial peptide pheromone plantaricin A with model membranes: Implications for a novel mechanism of action. Biochim Biophys Acta Biomembr. 2006;1758(9):1461-74.

https://doi.org/10.1016/j.bbamem.2006.03.037

27. Kristiansen PE, Fimland G, Mantzilas D, Nissen-Meyer J. Structure and mode of action of the membrane-permeabilizing antimicrobial peptide pheromone plantaricin A. J Biol Chem. 2005;280(24):22945-50. https://doi.org/10.1074/jbc.M501620200

28. Bonomo MG, Ricciardi A, Zotta T, Parente E, Salzano G. Molecular and technological characterization of lactic acid bacteria from traditional fermented sausages of Basilicata region (Southern Italy). Meat Sci. 2008;80(4):1238-48. https://doi.org/10.1016/j.meatsci.2008.05.032

29. Leisner JJ, Millan JC, Huss HH, Larsen LM. Production of histamine and tyramine by lactic acid bacteria isolated from vacuum-packaged sugar-salted fish. J Appl Microbiol. 1994;76(5):417-23.

30. Emborg J, Laursen BG, Rathjen T, Dalgaard P. Microbial spoilage and formation of biogenic amines in fresh and thawed modified atmosphere-packed salmon (Salmo salar) at $2{ }^{\circ} \mathrm{C}$. J Appl Microbiol. 2002;92(4):790-9. https://doi.org/10.1046/j.1365-2672.2002.01588.x

31. Bover Cid S, Miguélez-Arrizado MJ, Becker B, Holzapfel WH, Vidal-Carou MC. Amino acid decarboxylation by Lactobacillus curvatus CTC273 affected by the $\mathrm{pH}$ and glucose availability. Food Microbiol. 2008;25(2):269-77.

https://doi.org/10.1016/j.fm.2007.10.013

32. Moreno-Arribas MV, Polo MC, Jorganes F, Muñoz R. Screening of biogenic amine production by lactic acid bacteria isolated from grape must and wine. Int J Food Microbiol. 2003;84(1):117-23.

https://doi.org/10.1016/S0168-1605(02)00391-4

33. Rodgers S. Preserving non-fermented refrigerated foods with microbial cultures - A review. Trends Food Sci Technol. 2001;12(8):276-84.

https://doi.org/10.1016/S0924-2244(01)00093-0

34. Gardini F, Tofalo R, Suzzi G. A survey of antibiotic resistance in Micrococcaceae isolated from Italian dry fermented sausages. J Food Prot. 2003;66(6):937-45.

https://doi.org/10.4315/0362-028X-66.6.937

35. Martín B, Garriga M, Hugas M, Bover-Cid S, Veciana-Nogués MT, Aymerich T. Molecular, technological and safety characterization of Gram-positive catalase-positive cocci from slightly fermented sausages. Int J Food Microbiol. 2006;107(2):148-58.

https://doi.org/10.1016/j.ijfoodmicro.2005.08.024 
36. Ramesh D, Vinothkanna A, Rai AK, Vignesh VS. Isolation of potential probiotic Bacillus spp. and assessment of their subcellular components to induce immune responses in Labeo rohita against Aeromonas hydrophila. Fish Shellfish Immunol. 2015;45(2):268-76.

https://doi.org/10.1016/j.fsi.2015.04.018

37. De Smet I, Van Hoorde L, Vande Woestyne M, Christiaens H, Verstraete W. Significance of bile salt hydrolytic activities of lactobacilli. J Appl Microbiol. 1995;79(3):292-301.

https://doi.org/10.1111/j.1365-2672.1995.tb03140.x

38. Mukherjee A, Ghosh K. Antagonism against fish pathogens by cellular components and verification of probiotic properties in autochthonous bacteria isolated from the gut of an Indian major carp, Catla catla (Hamilton). Aquacult Res.
2014;47(7):2243-55.

https://doi.org/10.1111/are.12676

39. Dutta D, Banerjee S, Mukherjee A, Ghosh K. Selection and probiotic characterization of exoenzyme-producing bacteria isolated from the gut of Catla catla (Actinopterygii: Cypriniformes: Cyprinidae). Acta Ichthyol Piscat. 2015; 45(4):373-84.

https://doi.org/10.3750/AIP2015.45.4.05

40. Yonekura L, Sun H, Soukoulis C, Fisk I. Microencapsulation of Lactobacillus acidophilus NCIMB 701748 in matrices containing soluble fibre by spray drying:Technological characterization, storage stability and survival afer in vitro digestion. J Funct Foods. 2014;6:205-14.

https://doi.org/10.1016/j.jff.2013.10.008 